\title{
Measuring Residents Satisfaction Levels of Public Housing in Maiduguri Metropolis of Borno State, Nigeria
}

\author{
Abubakar Mammadi ${ }^{1}$, Habu Mallam Baba ${ }^{1}$, Sadiq Tukur ${ }^{1}$, Abdul Azeez Adam Muhammad ${ }^{1}$, \\ Umar Abdullahi $^{2}$
}

${ }^{1}$ Abubakar Tafawa Balewa University

Tafawa Balewa Way, P. M. B. 0248, Bauchi, 740272, Nigeria

${ }^{2}$ Ministry of Land and Housing

P. M. B. 7023, Dutse, Nigeria

DOI: $10.22178 /$ pos.56-3

JEL Classification: 018

Received 29.02.2020

Accepted 28.03.2020

Published online 31.03.2020

Corresponding Author:

Abubakar Mammadi

abubakarmammadi@gmail.com

(C) 2020 The Authors. This article

is licensed under a Creative Commons

Attribution 4.0 License @ (1)

\begin{abstract}
This study aims to evaluate the residents' satisfaction with public housing in the Maiduguri metropolis. The study assessed the levels of quality of housing components, occupants' preference and satisfaction. The study adopted a quantitative approach and data were collected through a questionnaire survey from 265 household heads of the housing estate proportionately selected from the target population in Maiduguri metropolis. The data collected were subjected to descriptive and inferential statistics with mean ranking, frequency distribution and multiple regression analysis to achieve the research aim. The study showed that quality of building component, Condition of a bedroom, condition of living room, condition of the roof, condition of finishing and condition of the kitchen were ranked as very good and condition of the store, condition of the dining area, condition of garage and condition of toilets were good in the study area, while public housing quality and preference significantly influence occupants' satisfaction in Maiduguri metropolis. The research recommended that occupant peculiarities should be integrated into the design and development of housing estate. This will ensure that the satisfaction of the occupants is well co-opted in the development and therefore lead to higher satisfaction and functionality of the estates. The provision of facilities and amenities in public housing estates should be based on the occupant requirements and peculiarities. This will lead to the optimal utilization of the estate after development.
\end{abstract}

Keywords: Quality; Components; Preference; Satisfaction; Public Housing.

\section{INTRODUCTION}

Public housing is the provision of low-cost housing by the government for civil occupancy. Even though public housing development policies are geared toward the satisfaction of housing occupants, the experience of building users was highly ignored in the real estate development process especially in the public sector [58]. The growing need for shelters has been on the increase without consideration for occupant needs and requirements. This is because Public housing policy structures tend to favor architects' preferences, with an overall target of low costing, while there is a need for buildings to serve the needs of people who use them $[58,68]$.
In another clime [26] revealed that quality plays an integral part in the construction industry. Further stressing that to build customer confidence the quality of its work should be done according to the developed quality assurance program. However, [5] revealed that there have been instances of building failures in different parts of the country, cases of abandonment of housing projects mid-way and projects failing to meet the requirements even after execution, concluding further that the success of projects can only be measured in terms of the achievement of quality. With the above statement from scholars therefore it is germane to note that the success of every construction work is to provide a qualita- 
tive housing accommodation that meets the housing needs and requirements of individual occupants.

The amount of quality work influences household preferences for housing and thus influences satisfaction. Quality is, therefore, an attribute of occupants' preferences for housing. The study of housing preferences is indispensable and priorities' study where residents' taste and preference for housing are needed to ensure occupants' satisfaction through the production of qualitative housing. As a commodity that is largely produced in the private sector, housing is developed to appeal to different consumers' tastes and preferences [112]. Hence, there is a need to determine whether there is a correspondence between the types of housing supplied in the market and the types of housing that people want. However, a study by [93] shows that preferences are inherently unstable and can be expected to change for a specific household whenever significant changes in the constraints occur. That is why [78] stated that to develop a housing unit that satisfies its residents, it is important to understand the characteristics of existing and prospective residents. Invariably, a consensus is needed to be keyed in and reflected the common attributes of the household in drawing a standard for quality assurance framework by every partner in the building industry be it government or private individual.

Consequently, this study will strictly relate to public housing estates. As observed by [76] certain types of housing are supported and even promoted by public policy through for example tax policy, land use planning techniques and direct and indirect subsidies. Housing is a commodity the choice of which is characterized by complex individual attributes. The study on measurement of residents' satisfaction levels of public housing in Maiduguri is meant to explore on the most common attributes that influence individual residents choice of housing in the study area and see whether such attribute is in tandem with already built public estates but if not how these attribute can be captured in the statement of government policy so that an appreciable level of household satisfaction can be achieved. To this, the study evaluates the residents' satisfaction levels of public housing in the study area.

Statement of the Problem. It has been revealed that international concerns have been growing over the deteriorating housing condition in urban areas of developing nations [3]. The issues of poor housing quality are, therefore, a global phenomenon which was further confirmed by [11] that though housing is regarded as the right of every individual, a great proportion of Nigerian population lives in substandard, deplorable and unsanitary residential environments. Authors [99] the quality of housing within any neighborhood should be such that satisfies minimum health standards and good living standard, but should also be affordable to all categories of households. However, [9, 30] opined that government investment in housing in the third world are limited and wasted on expensive projects designed to woo electorates rather than directed to meet real needs for housing. In addition to aforementioned [30] revealed that the nonconsideration of socio-economic parameters for an organization that is responsible for housing provision has been identified as one of the major reasons for the housing inadequacies and poor quality in most urban fringes of developing countries hence, Nigeria was not an exception.

While reviewing the literature on housing choice and preference, authors [8] submitted that those searching for home do not typically have concrete, well-defined preferences; rather, housing preference is (re)shape during the problemsolving process. Several studies including [63] and [79] assert that when choosing a housing option, decision-makers are subject to a variety of influences and must make a various trade-off. Revealing further that the process of choosing can encompass the interlinked influences of preference, market conditions, market availability, government regulations, real estate agents, friends, family as well as both internal and external personal factors such as lifestyle and socioeconomic status, it was on this premise that the issue of housing preference has widely researched because it provides valuable information for the planning and development of housing for various residential groups with different needs [75]. Parts of the problem assert [14] is that the traditional practices of implementing housing projects have often ignored the predominant themes and plurality of community perspectives and thus failed to effectively address the needs of the people.

On the issues of satisfaction [110] opined that the management of public housing by the government in most countries is often labeled with poor maintenance, low rentals and often than not, ten- 
ants are unsatisfied with their dwelling units. However, [106] observed that increasing attention for urban neighborhoods by policymakers caused a renewed interest in the neighborhood (dis)satisfaction. Therefore the combined effect of the problem is so glaring to the extent that psychological well-being can affect one's judgment about dwelling environment quality whose condition is lower than others, whereas failures of many housing projects can be linked to lack of participation and in-depth understanding of the community issues [14]. Authors [32] poor housing is to be held responsible for several social problems, including identifiable physical mental diseases of occupants' maladjustment of a different kind, low self-esteem of slum dwellers, barriers to economic improvement, etc.

Although there are several studies on various aspects of public housing such as housing quality assessment [11]; housing preferences of residents [112]; and assessment of residential satisfaction with public housing [90] in and around Nigeria using various dimension, none of the studies examined the relevance of housing quality and residents 'satisfaction of public housing. Thus the study identified this as a gap and intends to investigate the residents' satisfaction of public housing in Maiduguri, Borno State.

This study aims to assess the residents' satisfaction with public housing in Maiduguri, to suggest ways to improve housing quality and preference to meet the satisfaction of public housing in the study area.

\section{LITERATURE REVIEW}

Public Housing. According to [80], Public housing is often used as a generic term to refer to all

Publicly assisted housing, accordingly, it is a specific federal program created than in 1937, the low-rent public housing program as the first major federal rental housing assistance program. Further, the public housing program serves some of the poorest families in the nation, including persons who are elderly, persons who are living with disabilities and other families with and without children [80]. Concluding that Families who live in public housing generally pay rent equal to $30 \%$ of their adjusted gross income; average rents paid by public housing families lag substantially behind private market rents paid by similar families.
Authors [2], refer Public housing to a form of housing provision, which emphasizes the role of the State (government and its agencies) in helping to provide housing, particularly for poor, lowincome and more vulnerable groups in the society. Further describing it as taken varied forms in different geographical contexts and other descriptive terms sometimes used instead of public housing include; social housing, state-housing, state-sponsored housing, welfare housing, nonprofit housing, low-cost housing, affordable housing, and mass housing. In [57], Public housing is referred to as government-provided or subsidized housing projects, which presumes the inability of the private sector to fully meet the housing needs of the entire population, especially the low-income groups. It is also called 'social housing ' or 'state-housing'(in the United Kingdom) and 'welfare housing' (in the United States).

Accordingly, two broad approaches to public housing have been identified: Governmentprovided housing and Government-sponsored housing [84]. Public housing programs have been criticized for failing to provide quality, affordable and adequate housing units to the target population in most developing countries [94]. Yet studies have indicated that governments in developing countries are not relenting in their efforts at addressing the problem of providing adequate, affordable and sustainable housing [2].

Housing Quality. Authors [2, 80], defines quality as the acceptable level (standard) of something when compared to other things like it; how good or bad something is. Authors [51] viewed quality as the ability of products and processes to conform to established requirements, stating further that quality, as well as project success, in construction projects should be capable of being regarded as the fulfillment of expectation of those contributors and stakeholders involved in such projects. Invariably, quality is an attribute of standard [3]. Furthermore, [2, 3, 6] asserts that quality cannot be considered differently from the process by which it is considered.

Authors [3, 65] further affirm that standards in housing are a measure of acceptability at a given time, place, in a given set of cultural, technological and economic conditions. Consequently, the need for good housing quality is imperative. In a study [11] indicate that over an estimated billion of the world's city residents live in insufficient quality housing, mostly in the sprawling slums 
and squatter settlements in developing countries. Probably, this might not be far from the submission by [87] on the Global housing Research Initiative on American \& Caribbean country that established a preponderance evident gaps in their study to include the absence of a common standard for housing quality globally or in the region, and thus indicate limited methods of assessing housing quality that can be used to measure impacts across national programs or to serve as enforced targets.

However, [11] concluded on the study of housing quality that housing, in Nigeria, is in short supply, poor quality and expensive for the generality of the populace. It suffices to say that housing quality is just one of the preferences to satisfying the resident need and requirement in a housing estate. Therefore, measuring the housing quality through regular tenant satisfaction surveys has become an important tool and local governments in both the UK and the USA have regularly apply this tool to measuring housing satisfaction [12]. The essence of this measurement is to assess the level of, and ensure that households are satisfied with the provided housing and its services.

Authors $[2,41]$ explain that planners and designers have used several criteria over the years to evaluate housing quality. These include; economic criteria such as the relationship between rent and income, physical criteria such as the integrity of the dwelling and the present plumbing and fixtures, social criteria such as the incidence of diseases and the degree which overcrowding of housing occupies, they, however, concluded that housing quality is highly dependent on the appropriate strategies of housing provision in the country. Authors $[1,4,11]$ amongst others, established in their studies that inadequate or complete absence of infrastructure was a bane to economic and social development in Nigeria, an attestation to the afore-stated anomalies.

It was established in [3] that Good quality housing must possess a general layout of good appearance, structures built with good materials among others while general customs and habits of the people are given topmost consideration, but concluded that, the aforementioned qualities have not been the case in most public housing estates in Nigeria. The above review of studies shows how significant housing quality is to residents of a particular housing, hence it could be seen as a yardstick for measuring occupants' satisfaction. It is expedient to note also that housing Quality is now gaining global attention through various researches and studies hence, it is expected that if government and development partners will give it the attention it deserves within the proper context of the time, it would minimize if not curb the problems of infrastructural decay.

Authors [8] stated that a dwelling can provide more satisfaction to its residents if, besides being available, it meets the residents' requirements. This study is, therefore, one amongst many that will dwell on the impact of the quality of housing and the occupants' satisfaction

Housing Satisfaction. Satisfaction studies cut across a wide range of disciplines in the management and social sciences as well as the built environment. Generally speaking, satisfaction is a subjective evaluation of the performance of products or services in meeting the needs and expectations of users or customers $[15,56]$. Researchers have come to define housing satisfaction as an individual's subjective assessment of whether or not his/her needs are being met [92, 93, 105]. Similarly, [28] opined that Studies on residential satisfaction promote a better understanding of the key sources of satisfaction and dissatisfaction among residents; factors influencing their satisfaction levels; as well as how residents are most likely to react in the event of dissatisfaction with the housing conditions. Further examining satisfaction, [44] and [8] explained that satisfaction in housing means the sentiments of satisfaction and happiness to the housing place which creates these feelings. Satisfaction is generally taken to mean an evaluative attitude towards some object or experience [61]. More so Satisfaction with goods and services provided by public bodies has also emerged according to [61] "as a focus of research and a major subject of governmental interest in Organization for Economic Cooperation and Development countries". However, most research conducted on satisfaction in the public sector has been undertaken by public bodies themselves and has been directed to informing managerial decisions rather than addressing theoretical questions about expectations [61].

According to [24] and [8], housing is often viewed as an entity involving a large number of units displaying aspects such as physical quality, location, the standard of services offered by the government and private owners as well as neighborhood characteristics. Residential satisfaction has been used as a measure to examine the success of housing development projects. 
Resident satisfaction has been in use since the early 1960s as the basis for optimizing the architectural design of large housing developments, where feedback was collected from residents of housing projects about resident's views on the physical features of proposed housing developments and then feeding those views back into the design process.

Authors [41] defined residential satisfaction as the emotional response to a person's dwelling; the positive or negative feeling that the occupants have for where they reside, the premise on this definition by [40] signifies that residential satisfaction can either be positive or negative. The definition and assessment of satisfaction today use structured surveys followed by statistical correlation of variables [46]. In their study, authors [8] corroborate with the work of [29] and [48] who display similar views on the concept of housing satisfaction based on their observation on past studies. In their opinion, the concept of housing satisfaction has been used for four major objectives. It is the key to predict an individual's perception of the overall quality of life. It is also an indicator of an individual mobility which later changes the demand on housing and influences surrounding area change.

Thirdly, it is used as an ad hoc measurement of private sector development success as an evaluation tool to measure resident's acceptance of prevailing shortcomings for existing surrounding area development. Finally, housing satisfaction acts as a variable in determining the relationship between the resident's background and his attitude towards mobility. In another clime, Research has shown that living in socially undesirable housing has adverse social and psychological effects [31, 33, 81, 89, 107]. Also, [81] revealed poor housing to be held responsible for some social problems, including identifiable physical and mental diseases of occupants' maladjustments of different kinds, intra-family and inter-family crowding, low self-esteem of slum dwellers, barriers to economic improvement, the problem of adequately educating the children.

Affirming the aforementioned indices [98] stated that $90 \%$ of area boys and girls are products of poor housing and homelessness. It is crucial to note therefore that the studies of housing satisfaction help to predict the positive and negative influences which aim to appreciate the need and aspiration of the individual household for maximum housing satisfaction and improve housing policy.
Measuring of Housing Satisfaction. Authors [53] observed that Neighbourhood characteristics, public facilities, and housing characteristics to be the main factors of residential satisfaction further identified three (3) housing characteristics that determine housing satisfaction based on housing type, housing price, and housing size. However, authors [112] found that housing characteristics can be determined through demography variables such as age, gender, and household income, explaining further that with regards household income one may assume a greater satisfaction with higher income status.

According to [18] study, satisfaction can be measured on two levels; first is the overall level of housing satisfaction and second is the satisfaction with the various components of the dwelling. Accordingly, satisfaction indices can be selfweighting; this means the individual considers the housing attributes deemed necessary for the type of ideal housing he/she would like to have. Then the individual compares his/her ideal to his/her actual housing and weighs both in his/her mind to determine overall satisfaction based upon how well housing needs and aspirations are being met in conclusion it narrowed on four factors that influence housing satisfaction, namely, Age, education, household size, and housing quality. It suffices to say that there are numerous attributes used in the determination of housing satisfaction. However, a study by [8], affirm that housing satisfaction is associated with the personality characteristics of the residents. In the same vein, [96], perceived quality and physical comfort as variables contributing to housing satisfaction, while authors [69] emphasized that residents' relationship with management staff play an important role in influencing satisfaction. Similarly, [60] stressed homeownership and [42] concluded that aggregate income contributes to housing satisfaction.

Author [58] reviewed the factors influencing residential satisfaction to include physical surrounding, structural aspect, internal hygiene of the house, cleanliness, landscaping of the surrounding area, number and size of rooms, kitchen, bathrooms, study area, living room, privacy, bedrooms location, staircase, dining area, quality of physical attributes, the durability of building materials, structural soundness, potable water, sewage disposal system, electricity supply, connectivity to other areas, infrastructure, territorial dominance, and safe environment. 
It was further revealed that the housing condition which encompasses the physical state of the house and the immediate environments is significantly related to residential satisfaction. The studies reviewed show that a good housing physical attributes such as the room, floors, ceilings, wall, door, windows, toilets; and the serenity of the environment in terms of cleanliness, safety, aesthetics, landscaping, location, services, and improved infrastructure are related to a higher level of residential satisfaction to the residents of the house and vice versa.

Occupants' Preference. Preferences are temporary states of mind about what kind of housing is desired and feasible at the current moment given the current constraints "included in the idea that preferences involve the choice of one option over another" [112]. Housing Preferences are expressions of values but expressed preference may not directly relate to a single or obvious value [109]. However, [93] expressed that Preferences are inherently unstable and can be expected to change for a specific household whenever significant changes in the constraints occur. The literature on preference centers around and mostly considered as special treatment (enactment of the zoning ordinance) rather than the implementation of the law to cover the general community. Hence, the intent as with most developed countries was to create an atmosphere for affordable housing.

\section{METHODOLOGY}

Research Population / Sample frame. The target population of this study were the total number of three residential housing estates of two/three bedroom units in the study area (Table 1-3).

Table 1 - Population, sample frame and sample size of the study

\begin{tabular}{|l|l|l|c|c|}
\hline \multicolumn{2}{|c|}{ Location } & $\begin{array}{c}\text { Name of } \\
\text { estate }\end{array}$ & $\begin{array}{c}\text { No. Of housing } \\
\text { units } \\
\text { (population) }\end{array}$ & Stratum \\
\hline 1 & Maiduguri & $\begin{array}{l}\text { Dikwa low- } \\
\text { cost }\end{array}$ & 98 & 32 \\
\hline 2 & Maiduguri & $\begin{array}{l}\text { Abbagana } \\
\text { taraf }\end{array}$ & 500 & 166 \\
\hline 3 & Maiduguri & $\begin{array}{l}202 \\
\text { housing } \\
\text { estate }\end{array}$ & 202 & 67 \\
\hline \multicolumn{2}{|l|}{} & 800 & 265 \\
\hline
\end{tabular}

Table 2 - Questionnaire Administration

\begin{tabular}{|l|l|l|}
\hline Questionnaire & Number & Response rate \\
\hline Administered & 265 & - \\
\hline Collected & 212 & $53 \%$ \\
\hline Valid & 190 & $48 \%$ \\
\hline
\end{tabular}

Table 3 - Demographic Information of the respondents

\begin{tabular}{|c|c|c|c|c|}
\hline No & Attributes & Options & Frequency & $\%$ \\
\hline \multirow[t]{3}{*}{1} & \multirow[t]{3}{*}{ Age } & Under 30 years & 13 & 6.8 \\
\hline & & 31 to 60 years & 157 & 82.6 \\
\hline & & Over 61 years & 20 & 10.5 \\
\hline \multirow[t]{3}{*}{2} & \multirow[t]{3}{*}{ Gender } & Male & 133 & 70.0 \\
\hline & & Female & 57 & 30.0 \\
\hline & & & 190 & 100.0 \\
\hline \multirow[t]{3}{*}{3} & \multirow{3}{*}{$\begin{array}{l}\text { How long } \\
\text { have you } \\
\text { lived here }\end{array}$} & Under one year & 1 & .5 \\
\hline & & $1-5$ years & 67 & 35.3 \\
\hline & & Over 5 years & 122 & 64.2 \\
\hline \multirow[t]{4}{*}{4} & \multirow{4}{*}{$\begin{array}{l}\text { How } \\
\text { often do } \\
\text { you stay } \\
\text { at home }\end{array}$} & Some times & 4 & 2.1 \\
\hline & & Most of the time & 50 & 26.3 \\
\hline & & $\begin{array}{l}\text { Evenings / } \\
\text { weekends }\end{array}$ & 106 & 55.8 \\
\hline & & Other & 30 & 15.8 \\
\hline \multirow[t]{4}{*}{5} & \multirow[t]{4}{*}{$\begin{array}{l}\text { Nature of } \\
\text { tenure }\end{array}$} & $\begin{array}{l}\text { It was allocated to } \\
\text { me }\end{array}$ & 124 & 65.3 \\
\hline & & $\begin{array}{l}\text { I bought it from the } \\
\text { person allocated to }\end{array}$ & 15 & 7.9 \\
\hline & & $\begin{array}{l}\text { I bought it much } \\
\text { later after } \\
\text { allocation }\end{array}$ & 7 & 3.7 \\
\hline & & I am a tenant & 44 & 23.2 \\
\hline
\end{tabular}

Sampling Techniques. The procedure for choosing the sample units from a population is known as sampling techniques [100]. For this study, stratify random sampling was employed; this is because the respondents were group according to housing estates.

Sample size. Author [71] stated that the sample must be of an optimum size i.e., it should neither be excessively large nor too small. Authors [73] revealed a simplified table for estimating the confidence level needed from a given population. Thus, indicating a randomly chosen sample from a given population to falls within 0.05 sample proportion with a 95 percent level of confidence. Thus using [73] table the sample size of 265 out of a population of 800 was chosen. Thus, a sample size of 265 will be adopted.

Method of data collection. The instrument adopted for data collection was a questionnaire, thus to ensure smooth investigation of issues the study has adopted the use of structured ques- 
tions where a predetermined set of questions was employed to cross-examine residents in the study area. The use of a close-ended questionnaire was vital to eliminate the subjective bias of interest in questions.

Method of Data Analysis and Presentation. The study employed the use of descriptive and inferential statistics to analyze the data collected. Statistical Package for Social Science (SPSS, version 23) was adopted for statistical analysis of the data collected from the questionnaire survey.

Normality of the Field data. Before multiple regression analysis to answer the research question, a normality test was carried out using skewness and kurtosis to meet the assumption of multiple regression analysis as suggested in [104]. This is to show that the data is normally distributed and acceptable for the analysis. Thus it shows neither to skew to the right nor left hence, the data distribution ranges from -1.291 to -.001 which is within the acceptable range of $+/-2$ recommended in [111].

The Reliability of the constructs. The reliability of the constructs was analyzed by finding Cronbach's alpha as suggested by [104]. Overall Cronbach's alpha for the questionnaire was 0.965 . This means that the questionnaire as a whole is reliable and acceptable. The reliability test for the field data presented in the Table 4 below showed that the Cronbach's alphas obtained for each of the constructs are above acceptable alpha of 0.7 .

Table 4 - Reliability Results of the Field Data

\begin{tabular}{|l|c|c|c|}
\hline \multicolumn{1}{|c|}{ Constructs } & $\begin{array}{c}\text { Cronbach's } \\
\text { Alpha }\end{array}$ & $\begin{array}{c}\text { Standardized } \\
\text { Cronbach's } \\
\text { Alpha }\end{array}$ & $\begin{array}{c}\text { N of } \\
\text { Items }\end{array}$ \\
\hline $\begin{array}{l}\text { Building } \\
\text { Components } \\
\text { Quality }\end{array}$ & .922 & .924 & 9 \\
\hline $\begin{array}{l}\text { Nonphysical } \\
\text { features } \\
\text { (Intangible) } \\
\text { Quality }\end{array}$ & .777 & .807 & 8 \\
\hline $\begin{array}{l}\text { Physical } \\
\text { features } \\
\text { (Tangible) } \\
\text { Quality }\end{array}$ & .931 & .932 & 11 \\
\hline $\begin{array}{l}\text { Building } \\
\text { components } \\
\text { Preference }\end{array}$ & .940 & .942 & 8 \\
\hline $\begin{array}{l}\text { Nonphysical } \\
\text { features } \\
\text { (Intangible) } \\
\text { Preference }\end{array}$ & .958 & .958 & 8 \\
\hline
\end{tabular}

\begin{tabular}{|l|c|c|c|}
\hline \multicolumn{1}{|c|}{ Constructs } & $\begin{array}{c}\text { Cronbach's } \\
\text { Alpha }\end{array}$ & $\begin{array}{c}\text { Standardized } \\
\text { Cronbach's } \\
\text { Alpha }\end{array}$ & $\begin{array}{c}\text { N of } \\
\text { Items }\end{array}$ \\
\hline $\begin{array}{l}\text { Physical } \\
\text { features } \\
\text { (Tangible) } \\
\text { Preference }\end{array}$ & .937 & .938 & 11 \\
\hline $\begin{array}{l}\text { Building } \\
\text { Components } \\
\text { Satisfaction }\end{array}$ & .965 & .967 & 8 \\
\hline $\begin{array}{l}\text { Nonphysical } \\
\text { features } \\
\text { (Intangible) } \\
\text { Satisfaction }\end{array}$ & .956 & .959 & 8 \\
\hline $\begin{array}{l}\text { Physical } \\
\text { features } \\
\text { (Tangible) } \\
\text { Satisfaction }\end{array}$ & .958 & .959 & 11 \\
\hline
\end{tabular}

Criteria for ranking. As seven (7) Likert scale was used in data collection and analysis, the same ranking scale was used in a mean ranking scale (Table 5).

Table 5 - Seven (5) Likert scale criteria for building performance ranking

\begin{tabular}{|c|c|c|c|c|}
\hline No & Quality & Preference & Satisfaction & $\begin{array}{l}\text { Ranking } \\
\text { scale }\end{array}$ \\
\hline 1 & Excellent & $\begin{array}{l}\text { Extremely } \\
\text { important }\end{array}$ & $\begin{array}{l}\text { Extremely } \\
\text { satisfied }\end{array}$ & $\begin{array}{ll}6.01 \\
7.00\end{array}$ \\
\hline 2 & Very good & $\begin{array}{l}\text { Very } \\
\text { important }\end{array}$ & Very satisfied & $\begin{array}{l}5.01 \\
6.00\end{array}$ \\
\hline 3 & Good & Important & Satisfied & $\begin{array}{l}4.01 \\
5.00\end{array}$ \\
\hline 4 & $\begin{array}{l}\text { Neither } \\
\text { good nor } \\
\text { poor }\end{array}$ & Neutral & \begin{tabular}{l|} 
Neither \\
satisfied nor \\
dissatisfied
\end{tabular} & $\begin{array}{l}3.01 \\
4.00\end{array}$ \\
\hline 5 & Poor & \begin{tabular}{|l} 
Less \\
important
\end{tabular} & Dissatisfied & $\begin{array}{l}2.01 \\
3.00\end{array}$ \\
\hline 6 & Very poor & $\begin{array}{l}\text { Very less } \\
\text { important }\end{array}$ & \begin{tabular}{|l} 
Very \\
dissatisfied
\end{tabular} & $\begin{array}{l}1.01 \\
2.00\end{array}$ \\
\hline 7 & $\begin{array}{l}\text { Extremely } \\
\text { poor }\end{array}$ & $\begin{array}{l}\text { Extremely } \\
\text { less } \\
\text { important }\end{array}$ & $\begin{array}{l}\text { Extremely } \\
\text { dissatisfied }\end{array}$ & -1.00 \\
\hline
\end{tabular}

The scale on housing quality based on occupants' perception ranges between excellent and extremely poor, while scale for preference was based on extremely important and extremely less important. However, occupants' satisfaction rating ranges between extremely satisfied and extremely dissatisfied as in [17]. 


\section{RESULTS AND DISCUSSION}

The data analyses results and findings for each research question are presented below. The analysis results were presented in tables and findings were explain in textual forms. A 7-point Likert scale was used throughout the study with different constructs having similar or different scale descriptors.

Level of public housing Quality in Maiduguri metropolis. Descriptive statistics based on the mean ranking was carried out to assess the quality of public housing in Maiduguri metropolis, Borno State. The results showed the ranking, mean and standard deviation for each Item. Table 6 below shows the quality of public housing components in the Maiduguri metropolis.

Table 6 - Quality of building components in Maiduguri public housing

\begin{tabular}{|l|c|c|c|c|}
\hline \multicolumn{1}{|c|}{ Variables } & Mean & $\begin{array}{c}\text { Std. } \\
\text { Deviation }\end{array}$ & $\begin{array}{c}\text { Quality } \\
\text { (Level) }\end{array}$ & Rank \\
\hline $\begin{array}{l}\text { Condition of } \\
\text { bedroom }\end{array}$ & 5.2842 & 1.20986 & $\begin{array}{c}\text { Very } \\
\text { Good }\end{array}$ & 1 \\
\hline $\begin{array}{l}\text { Condition of } \\
\text { living room }\end{array}$ & 5.2579 & 1.06001 & $\begin{array}{l}\text { Very } \\
\text { Good }\end{array}$ & 2 \\
\hline $\begin{array}{l}\text { Condition of } \\
\text { roof }\end{array}$ & 5.0842 & 1.04059 & $\begin{array}{l}\text { Very } \\
\text { Good }\end{array}$ & 3 \\
\hline $\begin{array}{l}\text { Condition of } \\
\text { Finishing }\end{array}$ & 5.0105 & 1.20839 & $\begin{array}{l}\text { Very } \\
\text { Good }\end{array}$ & 4 \\
\hline $\begin{array}{l}\text { Condition of } \\
\text { kitchen }\end{array}$ & 5.0053 & 1.03124 & Good & 5 \\
\hline $\begin{array}{l}\text { Condition of } \\
\text { store }\end{array}$ & 4.9263 & 1.03118 & Good & 6 \\
\hline $\begin{array}{l}\text { Condition of } \\
\text { dining area }\end{array}$ & 4.9105 & 1.13034 & Good & 7 \\
\hline $\begin{array}{l}\text { Condition of } \\
\text { garage }\end{array}$ & 4.9105 & 1.31229 & Good & 8 \\
\hline $\begin{array}{l}\text { Condition of } \\
\text { toilets }\end{array}$ & 4.8053 & 1.25102 & Good & 9 \\
\hline
\end{tabular}

Overall Quality (Level) - 5.0216 (Very Good)

It shows that the qualities of public housing components that were highest, based on the sevenpoint measurement scale, were a condition of a bedroom with a mean score of 5.2842 ranked 1 among the housing quality, condition of living room with a mean score of 5.2579 ranked 2, condition of the roof with the mean score of 5.0842 ranked the 3, Condition of Finishing ranked the 4 with the mean score of 5.0105 and condition of kitchen ranked the 5 with a mean score of 5.0053 , followed by other housing condition which are a condition of the store, condition of the dining area, condition of garage and Condition of toilets with mean scores of 4.9263 , $4.9105,4.9105$ and 4.8053 , ranked the $6,7,8$, and 9 respectively.

However, the overall mean score for the level of housing condition components was 5.0216, which is very good.

Quality of Nonphysical (Intangible) features. Descriptive statistics based on the mean ranking was carried out to assess the Quality of Nonphysical (Intangible) features in Maiduguri metropolis, Borno State. The results showed the ranking, mean and standard deviation for each Item.

Table 7 below shows the Quality of Nonphysical (Intangible) features in the Maiduguri metropolis.

Table 7 - Quality of nonphysical (Intangible) features

\begin{tabular}{|l|c|c|c|c|}
\hline Variables & Mean & $\begin{array}{c}\text { Std. Devia- } \\
\text { tion }\end{array}$ & $\begin{array}{c}\text { Quality } \\
\text { (Level) }\end{array}$ & Rank \\
\hline $\begin{array}{l}\text { Condition of } \\
\text { privacy }\end{array}$ & 5.8474 & 1.20091 & $\begin{array}{c}\text { Very } \\
\text { Good }\end{array}$ & 1 \\
\hline $\begin{array}{l}\text { Condition of } \\
\text { ventilation }\end{array}$ & 5.7842 & .95992 & $\begin{array}{c}\text { Very } \\
\text { Good }\end{array}$ & 2 \\
\hline $\begin{array}{l}\text { Condition of } \\
\text { internal ap- } \\
\text { pearance }\end{array}$ & 5.2947 & 1.00131 & $\begin{array}{c}\text { Very } \\
\text { Good }\end{array}$ & 3 \\
\hline $\begin{array}{l}\text { Condition of } \\
\text { design }\end{array}$ & 5.2789 & 1.20452 & $\begin{array}{c}\text { Very } \\
\text { Good }\end{array}$ & 4 \\
\hline $\begin{array}{l}\text { Condition of } \\
\text { external ap- } \\
\text { pearance }\end{array}$ & 5.2000 & 1.02972 & $\begin{array}{c}\text { Very } \\
\text { Good }\end{array}$ & 5 \\
\hline $\begin{array}{l}\text { Condition of } \\
\text { natural light- } \\
\text { ing }\end{array}$ & 5.0158 & 1.09097 & $\begin{array}{c}\text { Very } \\
\text { Good }\end{array}$ & 6 \\
\hline $\begin{array}{l}\text { Condition of } \\
\text { light gener- } \\
\text { ally }\end{array}$ & 4.8211 & .95927 & Good & 7 \\
\hline $\begin{array}{l}\text { Condition of } \\
\text { artificial } \\
\text { lighting }\end{array}$ & 3.5684 & 1.83241 & $\begin{array}{l}\text { Neither } \\
\text { good nor } \\
\text { poor }\end{array}$ & 8 \\
\hline
\end{tabular}

Overall Quality (Level) - 5.1013 (Very Good)

It shows that the Quality of Nonphysical (Intangible) features that were highest, based on the seven-point measurement scale, were Condition of privacy, Condition of ventilation, Condition of internal appearance, Condition of design, Condition of external appearance and Condition of natural lighting with the mean scores of 5.8474, $5.7842,5.2947,5.2789,5.2000$ and 5.0158 ranked the $1,2,3,4,5$, and 6 respectively, and the 
least quality of nonphysical feature are Condition of light generally and Condition of artificial lighting with means scores of 4.8211 and 3.5684 ranked 7 and 8 respectively. However, the overall mean score for determining the level of Quality of Nonphysical features (Intangible) was 5.1013, which means very good quality.

Quality of physical (tangible) features. Descriptive statistics based on the mean ranking was carried out to assess the Quality of Physical features (Tangible) in Maiduguri metropolis, Nigeria. The results showed the ranking, mean and standard deviation for each Item.

Table 8 below shows the Quality of Physical (Tangible) features in the Maiduguri metropolis.

Table 8 - Quality of physical (tangible) features

\begin{tabular}{|l|c|c|c|c|}
\hline \multicolumn{1}{|c|}{ Variables } & Mean & $\begin{array}{c}\text { Std. } \\
\text { Deviation }\end{array}$ & $\begin{array}{c}\text { Quality } \\
\text { (Level) }\end{array}$ & Rank \\
\hline $\begin{array}{l}\text { Condition of } \\
\text { electric facilities }\end{array}$ & 5.1105 & 1.18786 & $\begin{array}{c}\text { Very } \\
\text { Good }\end{array}$ & 1 \\
\hline Condition of wall & 5.0579 & 1.23948 & $\begin{array}{c}\text { Very } \\
\text { Good }\end{array}$ & 2 \\
\hline Condition of floor & 5.0526 & 1.09707 & $\begin{array}{c}\text { Very } \\
\text { Good }\end{array}$ & 3 \\
\hline $\begin{array}{l}\text { Condition of } \\
\text { plumbing } \\
\text { facilities }\end{array}$ & 5.0421 & 1.10234 & $\begin{array}{c}\text { Very } \\
\text { Good }\end{array}$ & 4 \\
\hline $\begin{array}{l}\text { Condition of } \\
\text { ceiling }\end{array}$ & 5.0368 & 1.00985 & $\begin{array}{c}\text { Very } \\
\text { Good }\end{array}$ & 5 \\
\hline $\begin{array}{l}\text { Condition of } \\
\text { heating facilities }\end{array}$ & 4.8579 & 1.18447 & Good & 6 \\
\hline $\begin{array}{l}\text { Condition of } \\
\text { doors/windows }\end{array}$ & 4.8263 & 1.22424 & Good & 7 \\
\hline $\begin{array}{l}\text { Condition of } \\
\text { cooling facilities }\end{array}$ & 4.8211 & 1.12197 & Good & 8 \\
\hline $\begin{array}{l}\text { Condition of nets } \\
\text { on window }\end{array}$ & 4.8000 & 1.26491 & Good & 9 \\
\hline Condition of fence & 4.7368 & 1.29476 & Good & 10 \\
\hline $\begin{array}{l}\text { Condition of } \\
\text { burglary proof }\end{array}$ & 4.7368 & 1.11470 & Good & 11 \\
\hline
\end{tabular}

Overall Quality (Level) - 4.9163 (Good)

It shows that the quality of Physical (Tangible) features that were most, based on the sevenpoint measurement scale, are Condition of electric facilities, Condition of the wall, Condition of the floor, Condition of plumbing facilities and Condition of the ceiling with the mean scores of $5.1105,5.0579,5.0526,5.0421$ and 5.0368 ranked the 1, 23,4 and 5 respectively. The other quality of physical features (tangible) is Condition of heating facilities, Condition of doors/windows, Condition of cooling facilities, Condition of nets on the window, Condition of fence and Condition of burglary proof with mean scores 4.8579, 4.8263, 4.8211, 4.8000, 4.7368 and 4.7368 ranked the $6,7,8,9,10$ and 11 respectively. Therefore, the overall mean scores to determine the level of Quality of Physical features (Tangible) in the Maiduguri metropolis was 4.9163.

Level of occupants' satisfaction with building components in Maiduguri public housing. Descriptive statistics based on the mean ranking was carried out to assess the occupants' satisfaction with the public housing components in Maiduguri metropolis, Borno State. The results showed the ranking, mean and standard deviation for each Item.

Table 9 below shows the occupants' satisfaction with the public housing components in Maiduguri metropolis.

Table 9 - Level of occupants' satisfaction with building components in Maiduguri public housing

\begin{tabular}{|l|c|c|c|c|}
\hline Variable & Mean & $\begin{array}{c}\text { Std. } \\
\text { Deviation }\end{array}$ & $\begin{array}{c}\text { Quality } \\
\text { (Level) }\end{array}$ & Rank \\
\hline $\begin{array}{l}\text { Condition of } \\
\text { bedroom }\end{array}$ & 5.4526 & 1.29524 & $\begin{array}{c}\text { Very } \\
\text { Satisfied }\end{array}$ & 1 \\
\hline $\begin{array}{l}\text { Condition of } \\
\text { living room }\end{array}$ & 5.3316 & 1.25591 & $\begin{array}{c}\text { Very } \\
\text { Satisfied }\end{array}$ & 2 \\
\hline $\begin{array}{l}\text { Condition of } \\
\text { store }\end{array}$ & 5.1947 & 1.03329 & $\begin{array}{c}\text { Very } \\
\text { Satisfied }\end{array}$ & 3 \\
\hline $\begin{array}{l}\text { Condition of } \\
\text { kitchen }\end{array}$ & 5.1895 & 1.04699 & $\begin{array}{c}\text { Very } \\
\text { Satisfied }\end{array}$ & 4 \\
\hline $\begin{array}{l}\text { Condition of } \\
\text { roof }\end{array}$ & 5.1737 & 1.06723 & $\begin{array}{c}\text { Very } \\
\text { Satisfied }\end{array}$ & 5 \\
\hline $\begin{array}{l}\text { Condition of } \\
\text { Finishing }\end{array}$ & 5.0158 & 1.19291 & $\begin{array}{c}\text { Very } \\
\text { Satisfied }\end{array}$ & 6 \\
\hline $\begin{array}{l}\text { Condition of } \\
\text { toilets }\end{array}$ & 4.9263 & 1.42348 & Satisfied & 7 \\
\hline $\begin{array}{l}\text { Condition of } \\
\text { dining area }\end{array}$ & 4.8053 & 1.20799 & Satisfied & 8 \\
\hline
\end{tabular}

Overall Quality (Level) - 5.1362 (Very Satisfied)

It shows that the occupants' satisfaction with the public housing that is highest, based on the seven-point measurement scale, is satisfaction with Condition of a bedroom, Condition of living room, Condition of the store, Condition of the kitchen, Condition of roof and Condition of Finishing with the mean scores of 5.4526, 5.3316, 5.1947, 5.1895, 5.1737 and 5.0158 and ranked the $1,2,3,4$ and 5 respectively, other occupants' satisfaction with the public housing is Condition 
of toilets and Condition of the dining area with the mean value of 4.9263 and 4.8053 ranked the 7 and 8 respectively. The mean score for assessing the level of occupants' satisfaction with the public housing component in Maiduguri metropolis was 5.1362, indicating very satisfied.

Occupants' Satisfaction with Nonphysical (Intangible) features. Descriptive statistics based on the mean ranking was carried out to assess the occupants' satisfaction with Nonphysical features (Intangible) in Maiduguri metropolis, Nigeria. The results showed the ranking, mean and standard deviation for each Item.

Table 10 below shows the occupants' satisfaction with Nonphysical (Intangible) features in Maiduguri metropolis.

Table 10 - Level of occupants' Satisfaction with Nonphysical (intangible) features

\begin{tabular}{|l|c|c|c|c|}
\hline \multicolumn{1}{|c|}{ Variable } & Mean & $\begin{array}{c}\text { Std. } \\
\text { Deviation }\end{array}$ & $\begin{array}{c}\text { Satisfaction } \\
\text { (Level) }\end{array}$ & Rank \\
\hline $\begin{array}{l}\text { Condition of } \\
\text { natural } \\
\text { lighting }\end{array}$ & 5.2105 & 1.08276 & $\begin{array}{c}\text { Very } \\
\text { Satisfied }\end{array}$ & 1 \\
\hline $\begin{array}{l}\text { Condition of } \\
\text { ventilation }\end{array}$ & 5.2105 & 1.08764 & $\begin{array}{c}\text { Very } \\
\text { Satisfied }\end{array}$ & 2 \\
\hline $\begin{array}{l}\text { Condition of } \\
\text { privacy }\end{array}$ & 5.1526 & 1.26527 & $\begin{array}{c}\text { Very } \\
\text { Satisfied }\end{array}$ & 3 \\
\hline $\begin{array}{l}\text { Condition of } \\
\text { internal } \\
\text { appearance }\end{array}$ & 5.0368 & 1.07088 & $\begin{array}{c}\text { Very } \\
\text { Satisfied }\end{array}$ & 4 \\
\hline $\begin{array}{l}\text { Condition of } \\
\text { external } \\
\text { appearance }\end{array}$ & 5.0053 & .95672 & $\begin{array}{c}\text { Very } \\
\text { Satisfied }\end{array}$ & 5 \\
\hline $\begin{array}{l}\text { Condition of } \\
\text { design }\end{array}$ & 4.9947 & 1.12921 & Satisfied & 6 \\
\hline $\begin{array}{l}\text { Condition of } \\
\text { artificial } \\
\text { lighting }\end{array}$ & 4.9789 & 1.24704 & Satisfied & 7 \\
\hline $\begin{array}{l}\text { Condition of } \\
\text { light } \\
\text { generally }\end{array}$ & 4.8526 & 1.33308 & Satisfied & 8 \\
\hline
\end{tabular}

Overall Quality (Level) - 5.0553 (Very Satisfied)

It shows that the occupants' satisfaction with Nonphysical (Intangible) features that are most, based on the seven-point measurement scale, are Condition of natural lighting, Condition of ventilation, Condition of privacy, Condition of internal appearance and Condition of external appearance with the mean scores 5.2105, 5.2105, 5.1526, 5.0368 and 5.0053 ranked the 1, 2, 3, 4 and 5 respectively. The other occupants' satisfac- tion with Nonphysical (intangible) features are Condition of design, Condition of artificial lighting and Condition of light generally with mean scores of 4.9947, 4.9789 and 4.8526 ranked the 6,7 and 8 respectively. Therefore, the overall mean score for assessing the level of occupants' satisfaction with nonphysical (Intangible) features in Maiduguri metropolis was 5.0553, indicating very satisfied.

Occupants' satisfaction with the quality of physical (tangible) features. Descriptive statistics based on the mean ranking was carried out to assess the occupants' satisfaction with Quality of Physical (Tangible) features in Maiduguri metropolis, Borno State. The results showed the ranking, mean and standard deviation for each Item. Table 11 below shows the occupants' satisfaction with Quality of Physical (tangible) features in Maiduguri metropolis.

Table 11 - Level of Occupants' Satisfaction with Quality of Physical (Tangible) features

\begin{tabular}{|c|c|c|c|c|}
\hline Variable & Mean & $\begin{array}{c}\text { Std. } \\
\text { Deviation }\end{array}$ & $\begin{array}{c}\text { Satisfaction } \\
\text { (Level) }\end{array}$ & Rank \\
\hline $\begin{array}{l}\text { Condition of } \\
\text { doors and } \\
\text { windows }\end{array}$ & 5.2368 & 1.10397 & $\begin{array}{c}\text { Very } \\
\text { Satisfied }\end{array}$ & 1 \\
\hline $\begin{array}{l}\text { Condition of } \\
\text { ceiling }\end{array}$ & 5.1737 & .97391 & $\begin{array}{c}\text { Very } \\
\text { Satisfied }\end{array}$ & 2 \\
\hline $\begin{array}{l}\text { Condition of } \\
\text { floor }\end{array}$ & 5.1211 & 1.03947 & $\begin{array}{c}\text { Very } \\
\text { Satisfied }\end{array}$ & 3 \\
\hline $\begin{array}{l}\text { Condition of } \\
\text { nets on } \\
\text { window }\end{array}$ & 5.1000 & 1.10578 & $\begin{array}{c}\text { Very } \\
\text { Satisfied }\end{array}$ & 4 \\
\hline $\begin{array}{l}\text { Condition of } \\
\text { plumbing } \\
\text { facilities }\end{array}$ & 5.1000 & 1.04172 & $\begin{array}{c}\text { Very } \\
\text { Satisfied }\end{array}$ & 5 \\
\hline $\begin{array}{l}\text { Condition of } \\
\text { electric } \\
\text { facilities }\end{array}$ & 5.0579 & .93255 & $\begin{array}{c}\text { Very } \\
\text { Satisfied }\end{array}$ & 6 \\
\hline $\begin{array}{l}\text { Condition of } \\
\text { burglary } \\
\text { proof }\end{array}$ & 5.0474 & 1.18762 & $\begin{array}{c}\text { Very } \\
\text { Satisfied }\end{array}$ & 7 \\
\hline $\begin{array}{l}\text { Condition of } \\
\text { fence }\end{array}$ & 5.0316 & .99153 & $\begin{array}{c}\text { Very } \\
\text { Satisfied }\end{array}$ & 8 \\
\hline $\begin{array}{l}\text { Condition of } \\
\text { wall }\end{array}$ & 5.0000 & 1.03892 & Satisfied & 9 \\
\hline $\begin{array}{l}\text { Condition of } \\
\text { cooling } \\
\text { facilities }\end{array}$ & 4.7053 & 1.20294 & Satisfied & 10 \\
\hline $\begin{array}{l}\text { Condition of } \\
\text { heating } \\
\text { facilities }\end{array}$ & 4.7000 & 1.20822 & Satisfied & 11 \\
\hline
\end{tabular}

Overall Quality (Level) - 5.0249 (Very Satisfied) 
It shows that the occupants' satisfaction with Quality of Physical (tangible) features that are most, based on the seven-point measurement scale, are Condition of doors and windows, Condition of the ceiling, Condition of the floor, Condition of nets on the window, Condition of plumbing facilities, Condition of electric facilities, Condition of burglary proof, Condition of fence and Condition of the wall with the mean scores 5.2368, 5.1737, 5.1211, 5.1000, 5.1000, 5.0579, $5.0474,5.0316$ and 5.0000 ranked the 1, 2, 3, 4, 5, $6,7,8$ and 9 respectively. The least occupants' satisfaction with Quality of Physical (tangible) features are Condition of cooling facilities and Condition of heating facilities with mean scores of 4.7053 and 4.7000 ranked the 10 and 11 respectively. However, the overall mean score for assessing the level of occupants' satisfaction with Quality of physical (tangible) features in the Maiduguri metropolis was 5.0249 indicating a very satisfying level.

Preference of building components that occupiers need in public housing. Descriptive statistics based on the mean ranking was carried out to assess the components attributes that occupiers need in a public housing estate in Maiduguri metropolis, Borno State. The results showed the ranking, mean and standard deviation for each Item.

Table 12 below shows the preference of building components in a public housing estate in Maiduguri metropolis that occupiers needs in a public housing estate in the study area that is most, based on the seven-point measurement scale, are Condition of bedroom and toilets with mean scores of 6.1632 and 6.0211 and ranked the 1 and 2 respectively.

Table 12 - Preference of Building Components that Occupiers need in Public Housing

\begin{tabular}{|c|c|c|c|c|}
\hline Variables & Mean & $\begin{array}{c}\text { Std. } \\
\text { Deviation }\end{array}$ & $\begin{array}{c}\text { Preferable } \\
\text { (Level) }\end{array}$ & Rank \\
\hline Bedroom & 6.1632 & 1.06890 & $\begin{array}{l}\text { Extremely } \\
\text { important }\end{array}$ & 1 \\
\hline Toilets & 6.0211 & 1.18169 & $\begin{array}{l}\text { Extremely } \\
\text { important }\end{array}$ & 2 \\
\hline $\begin{array}{l}\text { Living } \\
\text { Room }\end{array}$ & 5.9474 & 1.20289 & $\begin{array}{c}\text { Very } \\
\text { important }\end{array}$ & 3 \\
\hline Roof & 5.7526 & 1.12069 & $\begin{array}{c}\text { Very } \\
\text { important }\end{array}$ & 4 \\
\hline Finishing & 5.7211 & 1.00321 & $\begin{array}{c}\text { Very } \\
\text { important }\end{array}$ & 5 \\
\hline Store & 5.6895 & 1.08056 & $\begin{array}{c}\text { Very } \\
\text { important }\end{array}$ & 6 \\
\hline
\end{tabular}

\begin{tabular}{|l|c|c|c|c|}
\hline Variables & Mean & $\begin{array}{c}\text { Std. } \\
\text { Deviation }\end{array}$ & $\begin{array}{c}\text { Preferable } \\
\text { (Level) }\end{array}$ & Rank \\
\hline Kitchen & 5.6263 & 1.20946 & $\begin{array}{c}\text { Very } \\
\text { important }\end{array}$ & 7 \\
\hline $\begin{array}{l}\text { Dining } \\
\text { Area }\end{array}$ & 5.1316 & 1.44330 & $\begin{array}{c}\text { Very } \\
\text { important }\end{array}$ & 8 \\
\hline
\end{tabular}

Overall Quality (Level) - 5.7566 (Very important)

Other Preferences of building components that occupiers need in public housing are living room, roof, Finishing, store, kitchen and dining area with mean scores of 5.9474, 5.7526, 5.7211, $5.6895,5.6263$ and 5.1316 ranked the $3,4,5$ and 6 respectively. Therefore, the overall mean score for assessing the Preference of building components that occupiers need in public housing in the Maiduguri metropolis was 5.7566 indicating very important needs.

Preference of nonphysical (intangible) features that occupiers need in public housing. Descriptive statistics based on the mean ranking was carried out to assess the Preference nonphysical (intangible) features that occupiers need in a public housing estate in Maiduguri metropolis, Borno State. The results showed the ranking, mean and standard deviation for each Item.

Table 13 below shows the Nonphysical (intangible) features that occupiers need in a public housing estate in Maiduguri metropolis.

Table 13 - Preference of nonphysical (intangible) features that occupiers need in public housing

\begin{tabular}{|l|l|l|l|l|}
\hline Variables & Mean & $\begin{array}{l}\text { Std. } \\
\text { Deviation }\end{array}$ & $\begin{array}{l}\text { Preferable } \\
\text { (Level) }\end{array}$ & Rank \\
\hline Privacy & 6.0000 & 1.31334 & $\begin{array}{l}\text { Extremely } \\
\text { important }\end{array}$ & 1 \\
\hline Ventilation & 5.9105 & 1.25458 & $\begin{array}{l}\text { Very } \\
\text { important }\end{array}$ & 2 \\
\hline $\begin{array}{l}\text { Light } \\
\text { Generally }\end{array}$ & 5.7316 & 1.04732 & $\begin{array}{l}\text { Very } \\
\text { important }\end{array}$ & 3 \\
\hline $\begin{array}{l}\text { Internal } \\
\text { Appearance }\end{array}$ & 5.6000 & 1.27574 & $\begin{array}{l}\text { Very } \\
\text { important }\end{array}$ & 4 \\
\hline $\begin{array}{l}\text { Natural } \\
\text { Lighting }\end{array}$ & 5.5684 & 1.25274 & $\begin{array}{l}\text { Very } \\
\text { important }\end{array}$ & 5 \\
\hline $\begin{array}{l}\text { External } \\
\text { Appearance }\end{array}$ & 5.5211 & 1.13019 & $\begin{array}{l}\text { Very } \\
\text { important }\end{array}$ & 6 \\
\hline $\begin{array}{l}\text { Design } \\
\text { imp }\end{array}$ & 5.4842 & 1.25873 & $\begin{array}{l}\text { Very } \\
\text { important }\end{array}$ & 7 \\
\hline $\begin{array}{l}\text { Artificial } \\
\text { Lighting }\end{array}$ & 5.1421 & 1.28311 & $\begin{array}{l}\text { Very } \\
\text { important }\end{array}$ & 8 \\
\hline
\end{tabular}

Remark - 5.6197 (Very important) 
It shows that the Nonphysical features (Intangible) that occupiers need in a public housing estate in the study area that is most, based on the seven-point measurement scale, are privacy with mean scores of 6.0000 ranked the 1 and followed by ventilation, light generally, internal appearance, natural lighting, external appearance, design and artificial lighting with their mean scores of $5.9105,5.7316,5.6000,5.5684,5.5211,5.4842$ and 5.1421 ranked the $2,3,4,5,6$, and, 7 respectively. However, the overall mean score for assessing the nonphysical (intangible) features that occupiers need in public housing in the Maiduguri metropolis was 5.6197, indicating very important needs.

Preference of physical (tangible) features that occupiers need in public housing. Descriptive statistics based on the mean ranking was carried out to assess the Preference of physical (tangible) features that occupiers needs in a public housing estate in Maiduguri metropolis, Borno State. The results showed the ranking, mean and standard deviation for each Item.

Table 14 shows the Preference of physical (tangible) features that occupiers need in a public housing estate in Maiduguri metropolis.

Table 14 - Preference of physical (tangible) features that occupiers needs in public housing

\begin{tabular}{|l|c|c|c|c|}
\hline Variable & Mean & $\begin{array}{c}\text { Std. } \\
\text { Deviation }\end{array}$ & $\begin{array}{c}\text { Preferable } \\
\text { (Level) }\end{array}$ & Rank \\
\hline $\begin{array}{l}\text { Burglary } \\
\text { Proof }\end{array}$ & 6.0895 & 1.02735 & $\begin{array}{c}\text { Extremely } \\
\text { Important }\end{array}$ & 1 \\
\hline $\begin{array}{l}\text { Nets On } \\
\text { Window }\end{array}$ & 6.0474 & 1.16513 & $\begin{array}{c}\text { Extremely } \\
\text { important }\end{array}$ & 2 \\
\hline $\begin{array}{l}\text { Doors And } \\
\text { Windows }\end{array}$ & 6.0263 & .99965 & $\begin{array}{c}\text { Extremely } \\
\text { important }\end{array}$ & 3 \\
\hline Fence & 5.9632 & 1.01508 & $\begin{array}{c}\text { Very } \\
\text { important }\end{array}$ & 4 \\
\hline Ceiling & 5.8895 & .92776 & $\begin{array}{c}\text { Very } \\
\text { important }\end{array}$ & 5 \\
\hline Floor & 5.8579 & 1.09632 & $\begin{array}{c}\text { Very } \\
\text { important }\end{array}$ & 6 \\
\hline Wall & 5.8000 & .88611 & $\begin{array}{c}\text { Very } \\
\text { important }\end{array}$ & 7 \\
\hline $\begin{array}{l}\text { Plumbing } \\
\text { Facilities }\end{array}$ & 5.7737 & 1.11571 & $\begin{array}{c}\text { Very } \\
\text { important }\end{array}$ & 8 \\
\hline $\begin{array}{l}\text { Electric } \\
\text { Facilities }\end{array}$ & 5.6947 & .98747 & $\begin{array}{c}\text { Very } \\
\text { important }\end{array}$ & 9 \\
\hline $\begin{array}{l}\text { Heating } \\
\text { Facilities }\end{array}$ & 5.4579 & 1.26232 & $\begin{array}{c}\text { Very } \\
\text { important }\end{array}$ & 10 \\
\hline $\begin{array}{l}\text { Cooling } \\
\text { Facilities }\end{array}$ & 5.4211 & 1.26891 & $\begin{array}{c}\text { Very } \\
\text { important }\end{array}$ & 11 \\
\hline
\end{tabular}

Remark - 5.8201 (Very important)
It shows that the physical (tangible) features that occupiers needs in a public housing estate in the study area that are most, based on the sevenpoint measurement scale, are burglary proof, nets on window and doors and windows with mean scores of 6.0895, 6.0474 and 6.0263 and ranked the 1, 2 and 3 respectively. Other physical features (Tangible) that occupiers needs in public housing in the study area are fence, ceiling, floor, wall, plumbing facilities, electric facilities, heating facilities and cooling facilities with their mean scores of 5.9632, 5.8895, 5.8579, 5.8000, $5.7737,5.6947,5.4579$ and 5.4211 ranked the 4 , $5,6,7,8,9,10$ and 11 respectively. Therefore, the overall mean score for assessing the physical (tangible) features that occupiers needs in public housing in Maiduguri metropolis was 5.8201, indicating very important needs

Effects of component attributes' housing quality and occupants' preference on satisfaction in the study area. A regression analysis was carried out to assess the effects of housing quality and occupants' preference on the satisfaction of public housing in the study area. The result was presented in table 15 below indicated the value was $\mathrm{R}^{2}=.261, \mathrm{f}(2,187)=33.001, \mathrm{p}<.001$. The model produced an overall R-value of 0.511 and an Rsquare value of 0.261 with F-statistics of 33.001 which are significant as indicated by the $p$-value of 0.001 far below the recommended maximum of 0.05 [104]. This means that the independent variable building components Preference and building components quality explained $26.1 \%$ large significance $(\mathrm{p}<0.001)$ effect size on Building components Satisfaction in the study area.

Table 15 - Effects of component attributes' housing quality and occupants' preference on satisfaction in the study area

\begin{tabular}{|c|c|c|c|c|c|c|c|}
\hline \multicolumn{5}{|c|}{ Model Summary } & Df & F & Sig. \\
\cline { 1 - 5 } Model & $\mathrm{R}$ & $\begin{array}{c}\mathrm{R} \\
\text { Square }\end{array}$ & $\begin{array}{c}\text { Adjusted } \\
\text { R Square }\end{array}$ & $\begin{array}{c}\text { Std. Error } \\
\text { of the } \\
\text { Estimate }\end{array}$ & & & \\
\hline 1 & .511 & .261 & .253 & .92717 & 2 & 33.001 & .000 \\
\hline
\end{tabular}

Notes: a) Predictors: (Constant), Building components Preference, Building Components Quality; b) Dependent Variable: Building Components Satisfaction

Contribution of individual building components quality and building components preference on 
satisfaction. The regression analysis beta result indicating the individual effects of building components quality and building components preference on the satisfaction of public housing in the study area. The regression coefficient shown in table 16 below indicated that building component quality is the significant determinant of building component preference because the $\mathrm{p}$ value $(0.000)$ is less than the significance level at 0.05 .

Table 16 - Contribution of building components quality and building components preference on satisfaction

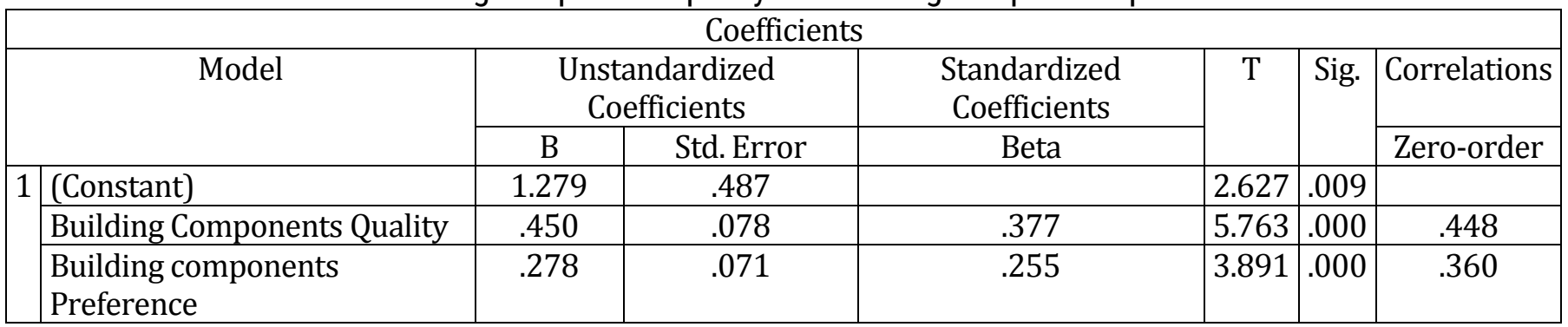

Notes: a) Dependent Variable: Building Components Satisfaction

Similarly, the contribution of building component preference into building component satisfaction is significant as shown by a t-statistics and pvalue of 3.891 and 0.00 respectively at a $5 \%$ level of significance. Therefore the building component quality and preference are what determines to build component satisfaction. Thus, if the building component quality increases by 1 Likert value, the Likert value of building component satisfaction will increase by 0.377 likewise an increase of building component preference by 1 Likert value will increase building component satisfaction by 0.255 . Hence, the building component quality and building component preference are what determine to build component satisfaction.

\section{CONCLUSION}

The findings from the survey carried out indicated that the quality of public housing condition of a bedroom, condition of living room, condition of the roof, condition of finishing and condition of the kitchen were very good in the study area and also the study revealed that occupant' satisfac- tion level with building components conditions of a bedroom, living rooms, stores, kitchen, roof, and finishing were very satisfied and others condition of toilet and condition of dining area were satisfied by the occupants in the area and study findings indicated that the occupant's preference with building components of a bedroom, toilets, living room, roof, finishing, stores, kitchen and dining in the study area. The study demonstrated a strong significant effect of building components, housing quality and occupants' preference on satisfaction.

Also, the research recommended occupants' peculiarities should be integrated into the design and development of housing estate. This will ensure that the satisfaction of the occupants is well co-opted in the development and therefore lead to higher satisfaction and functionality of the estate.

Also, the provision of facilities and amenities in public housing estate should be based on the occupants' requirements and peculiarities. This will lead to the optimal utilization of the estate after development.

\section{REFERENCES}

1. Abiodun, P. B., \& Segun, A. O. (2005). An Assessment of Housing Status in a Typical Nigerian Town. Journal of Applied Sciences, 5(3), 437-440. doi: 10.3923/jas.2005.437.440

2. Adeleye, A. O., Azeez, O. T., \& Yusuff, O. I. (2014). Perception of Housing Quality by Residents and Non Residents of Ibara Housing Estate, Abeokuta, Ogun State, Nigeria. American Journal of Human Ecology, 3(3). doi: 10.11634/216796221403586 
3. Adeleye, O. A, \& Anofojie, A. E. (2011). Housing Quality in Festac Town, Lagos State, Nigeria. Retrieved https://www.semanticscholar.org/paper/Housing-Quality-in-Festac-Town\%2C-LagosState\%2C-Adeleye-Anofojie/791c0632c90c155137d29ed97bde41b7bebb8deb

4. Aduda, G. T. (2007). Budget monitoring and Price Intelligence Unit (due process): A mechanism for combating corruption in infrastructure delivery in Nigeria. Case study. Retrieved from https://www.gov.uk/dfid-research-outputs/budget-monitoring-and-price-intelligence-unitdue-process-a-mechanism-for-combating-corruption-in-infrastructure-delivery-in-nigeria-casestudy

5. Afolarin, A. O. (2013). Factors affecting Quality in the Delivery of Public Housing Projects in Lagos State, Nigeria. International Journal of Engineering and Technology, 3(3), 332-336

6. Afon, A. O. (2000). The use of residents' Environmental Quality Indicator (EQI) data in the core residential housing improvement. In O. B. Akinbamijo, A. S. Famehinmi, D. R. Ogunsemi, \& A. Olotuah (Eds.), Effective housing in the 21st century Nigeria (pp. 115-122). Akure: The Environment Forum.

7. Aguinis, H. (2011). Organizational responsibility: Doing good and doing well. Retrieved from http://www.hermanaguinis.com/OR5.pdf

8. Ajayi, M., Nwosu, A., \& Ajani, Y. (2015). Students' satisfaction with hostel facilities in federal university of technology, Akure, Nigeria. European Scientific Journal, 11(34), 402-415.

9. Akeju, A. A. (2007). Challenges to providing affordable housing in Nigeria. In Emerging Urban Africa International Conference on Housing Finance in Nigeria. Abuja, October 2007. Retrieved from http://www.sciepub.com/reference/126719

10. Al-Momani, A. H. (2000). Examining service quality within construction processes. Technovation, 20(11), 643-651. doi: 10.1016/s0166-4972(00)00002-x

11. Anofojie, A. E., \& Kadiri, M. (2014). Housing quality assessment in selected public residential estates in Amuwo-Odofin LGA, Lagos, Nigeria. International Journal of Research, 2(6), 2311-2484.

12. Ayodeji, O. A. (2013). A study of liquidity in residential property sales transaction in lagos state Nigeria. Retrieved from

http://m.covenantuniversity.edu.ng/content/download/23659/160478/file/WABER+2013+Co nference+proceedings.pdf

13. Baur, D., \& Schmitz, H. P. (2011). Corporations and NGOs: When Accountability Leads to Cooptation. Journal of Business Ethics, 106(1), 9-21. doi: 10.1007/s10551-011-1057-9

14. Begum, H. (2015). Improving access to housing for low-income communities in Dhaka: from rhetoric to reality in community participation (Doctoral thesis). Retrieved from https://eprints.qut.edu.au/82794/4/Halima_Begum_Thesis.pdf

15. Bhatti, R. (2013). A study of library usage and satisfaction by social scientists at Bahauddin Zakariya University, Multan. Retrieved from https://digitalcommons.unl.edu/cgi/viewcontent.cgi?article=2341\&context=libphilprac

16. Boehm, T. P., \& Schlottmann, A. M. (1999). Does Home Ownership by Parents Have an Economic Impact on Their Children? Journal of Housing Economics, 8(3), 217-232. doi: 10.1006/jhec.1999.0248

17. Braunsberger, K., \& Gates, R. (2009). Developing inventories for satisfaction and Likert scales in a service environment. Journal of Services Marketing, 23(4), 219-225. doi: 10.1108/08876040910965557

18. Bromley, D. B. (2000). Psychological Aspects of Corporate Identity, Image and Reputation. Corporate Reputation Review, 3(3), 240-252. doi: 10.1057/palgrave.crr.1540117 
19. Bruns, A. S. (2017, March). The determinants of Corporate Social Responsibility: empirical evidence from the Netherland (Master's thesis). Retrieved from http://essay.utwente.nl/72020/1/BRUNS_MA_BMS.pdf

20. Carroll, C. (2016). The SAGE Encyclopedia of Corporate Reputation. Thousand Oaks: SAGE.

21. Choudhury, I. (2005). A conceptual model of resident satisfaction with reference to neighbourhood composition. Retrieved from

https://repository.up.ac.za/bitstream/handle/2263/10301/A\%20conceptual\%20model\%20of $\% 20$ resident $\% 20$ satisfaction.pdf?sequence=1\&isAllowed $=y$

22. Chun, R. (2005). Corporate reputation: Meaning and measurement. International Journal of Management Reviews, 7(2), 91-109. doi: 10.1111/j.1468-2370.2005.00109.x

23. Coakes, S. J., Steed, L. G., \& Dzidic, P. (2006). SPSS: Analysis without Anguish. Version 13.0 for Windows. Milton: John Wiley \& Sons.

24. Curley A. (2008). Deconcentrating poverty: program effects on neighborhood diversity and social cohesion. Conference paper for Housing Studies Association. York: University of York.

25. De Freitas, C., García-Ramirez, M., Aambø, A., \& Buttigieg, S. C. (2014). Transforming health policies through migrant user involvement: Lessons learnt from three European countries. Psychosocial Intervention, 23(2), 105-113. doi: 10.1016/j.psi.2014.07.007

26. Dharani, K. (2015). Study on negligence of quality assurance and proposing an effective framework for total quality management. International Journal of Research in Engineering and Technology, 04(02), 604-609. doi: 10.15623/ijret.2015.0402084

27. Doorley, J., \& Garcia, H. F. (2015). Reputation management: The key to successful public relations and corporate communication. New York: Routledge.

28. Ebiaride, E. C., \& Umeh, O. L. (2015). Factors Influencing Users' Satisfaction in Public and Private Estate in Lagos, Nigeria. ATBU Journal of Environmental Technology, 8(2), 30-41

29. Elsinga, M., \& Hoekstra, J. (2005). Homeownership and housing satisfaction. Journal of Housing and the Built Environment, 20(4), 401-424. doi: 10.1007/s10901-005-9023-4

30. Emakhu, S. E., \& Ubangari, A. Y. (2015). Analysis of housing quality in the peripheral Area of Lafia Town. International Journal of Geography and Regional Planning Research, 1(3), 9-17.

31. Eni, C. M. (2014). Evaluation of Residents' View on Affordability of Public Housing in Awka and Onitsha, Nigeria. Journal of Economics and Sustainable Development, 5(17), 126-143

32. Eni, Ch. M. (2015). Appraisal of occupants' satisfaction of social considerations of public housing in Anambra state, Nigeria. International Journal of Civil Engineering, Construction and Estate Management, 3(1), 15-33.

33. Fanning, R. M., \& Gaba, D. M. (2007). The Role of Debriefing in Simulation-Based Learning. Simulation in Healthcare: The Journal of the Society for Simulation in Healthcare, 2(2), 115-125. doi: $10.1097 /$ sih.0b013e3180315539

34. Feldman, P. M., Bahamonde, R. A., \& Velasquez Bellido, I. (2014). A new approach for measuring corporate reputation. Revista de Administração de Empresas, 54(1), 53-66. doi: 10.1590/s0034759020140102

35. Festus, I. A., \& Amos, I. O. (2005). Housing Policy in Nigeria: An Overview. American International Journal of Contemporary Research, 5(2), 53-59.

36. Fill, C., \& Roper, S. (2012). Corporate reputation: brand and communication. Harlow: Pearson.

37. Fombrun, C. J., \& Van Riel, C. B. M. (2003). Fame \& fortune: How the world's top companies develop winning reputations. Upper Saddle River: Pearson Education. 
38. Foreman, J., \& Argenti, P. A. (2005). How Corporate Communication Influences Strategy Implementation, Reputation and the Corporate Brand: An Exploratory Qualitative Study. Corporate Reputation Review, 8(3), 245-264. doi: 10.1057/palgrave.crr.1540253

39. Forrest, R. \& Lee, J. (2003). Housing and Social change: East-West Perspective. London: Routledge / Taylor \& Francis Group.

40. Francescato, G. (1963). Il dialetto di Erto. Zeitschrift Für Romanische Philologie (ZrP), 79(5-6). doi: 10.1515/zrph.1963.79.5-6.492

41. Francescato, G., Weidemann, S., \& Anderson, J. R. (1989). Evaluating the Built Environment from the Users' Point of View: An Attitudinal Model of Residential Satisfaction. Building Evaluation, 181198. doi: $10.1007 / 978-1-4899-3722-3 \_14$

42. Frank, B., \& Enkawa, T. (2009). Economic drivers of dwelling satisfaction. International Journal of Housing Markets and Analysis, 2(1), 6-20. doi: 10.1108/17538270910939538

43. Fu, X., Bhat, R. C., Pendyala, M. R., \& Vadlamani, S., \& Garikapati, M. V. (2015). Understanding the multiple Dimensions of Residential Choice. Retrieved from

http://www.caee.utexas.edu/prof/bhat/ABSTRACTS/MultiDimensionsofResChoiceGHDM_8Jun e2015.pdf

44. Geller, S. L., Abramson, A. J., \& de Leon, E. (2010). The Nonprofit Technology Gap - Myth or Reality? Retrieved from https://www.researchgate.net/publication/275336167_The_Nonprofit_Technology_Gap__Myth_or_Reality

45. Golin, A. (2003). Trust or Consequences: Build trust today or lose your market tomorrow. Nashville: AMACOM.

46. Goodchild, B. (2016). Homes, cities and neighbourhoods: planning and the residential landscapes of modern Britain. N. d.: Routledge.

47. Grunig, J. E., \& Hung, C. F. (2002). The effect of relationships on reputation and reputation on relationships: a cognitive, behavioral study. Retrieved from

https://www.researchgate.net/publication/247855482_The_effect_of_relationships_on_reputati on_and_reputation_on_relationships_A_cognitive

48. Hassanain, M. A. (2008). On the performance evaluation of sustainable student housing facilities. Journal of Facilities Management, 6(3), 212-225. doi: 10.1108/14725960810885989

49. Hatch, M. J., \& Schultz, M. (2009). Of Bricks and Brands. Organizational Dynamics, 38(2), 117-130. doi: 10.1016/j.orgdyn.2009.02.008

50. Helmig, B., Spraul, K., \& Ingenhoff, D. (2013). Under Positive Pressure. Business \& Society, 55(2), 151-187. doi: 10.1177/0007650313477841

51. Heravitorbati, A., Coffey, V., Trigunarsyah, B., \& Saghatforoush, E. (2011). Examination of process to develop a frame-work for better implementation of quality practices in building projects. In $2 n d$ International Conference on Construction and Project Management (ICCPM 2011), 16-18 September 2011, Grand Mercure Roxy Hotel, Singapore.

52. Hoang, D., Kopp, A., \& Chandler, J. A. (2015). Interactions betweenDrosophilaand its natural yeast symbionts-IsSaccharomyces cerevisiaea good model for studying the fly-yeast relationship? PeerJ, 3, e1116. doi: 10.7717/peerj.1116

53. Huang, Z., \& Du, X. (2015). Assessment and determinants of residential satisfaction with public housing in Hangzhou, China. Habitat International, 47, 218-230. doi: 10.1016/j.habitatint.2015.01.025

54. Hussain, I., Rashid, J. (2015). Determinants of the Quality of Housing in Poor and Non-Poor Household. Gomal University Journal of Research, 31(2), 87-98. 
55. Ibem, E. O., \& Amole, D. (2012). Residential Satisfaction in Public Core Housing in Abeokuta, Ogun State, Nigeria. Social Indicators Research, 113(1), 563-581. doi: 10.1007/s11205-012-0111-z

56. Ibem, O. E, Opoko, A. P, Adeboye, A., \& Amole, D. (2013). Performance evaluation of residential buildings in public housing estates in Ogun State, Nigeria: Users' satisfaction perspective. Frontiers of Architectural Research, 2(2), 178-190. doi: 10.1016/j.foar.2013.02.001

57. Ilesanmi, O. A., (2012). Housing Neighbourhood quality and Quality of life in public Housing in Lagos, Nigeria. International Journal for Housing science, 36(4), 231-240.

58. Ishiyaku, B. (2016). Evaluation of Nigerian public housing performance using occupants' experience and satisfaction (Doctoral thesis). Retrieved from https://www.researchgate.net/publication/319043444_EVALUATION_OF_NIGERIAN_PUBLIC_ HOUSING_PERFORMANCE_USING_OCCUPANTS'_EXPERIENCE_AND_SATISFACTION

59. Jafaar, M., Hasan, N. L., Mohamad, O., \& Ramaya, T. (2017). The Determinants of Housing Satisfaction Level: A Study on Residential Development Project by Penang Development Corporation (PDC). Retrieved from https://jurnalkemanusiaan.utm.my/index.php/kemanusiaan/article/download/144/137

60. James III, R. (2009). Customer satisfaction with apartment housing offered by Real Estate Investment Trusts (REITs). International Journal of Consumer Studies, 33(5), 572-580. doi: 10.1111/j.1470-6431.2009.00800.x

61. James, 0. (2007). Evaluating the Expectations Disconfirmation and Expectations Anchoring Approaches to Citizen Satisfaction with Local Public Services. Journal of Public Administration Research and Theory, 19(1), 107-123. doi: 10.1093/jopart/mum034

62. James, R. N. (2007). Multifamily Housing Characteristics and Tenant Satisfaction. Journal of Performance of Constructed Facilities, 21(6), 472-480. doi: 10.1061/(asce)08873828(2007)21:6(472)

63. Jansen, S. J. T., Coolen, H. C. C. H., \& Goetgeluk, R. W. (2011). Discussion and Directions for Future Research. The Measurement and Analysis of Housing Preference and Choice, 253-264. doi: 10.1007/978-90-481-8894-9_11

64. Jenkins, S. P., \& Maynard, A. K. (1983). Intergenerational Continuities in Housing. Urban Studies, 20(4), 431-438. doi: 10.1080/00420988320080791

65. Jiboye, D. (2010). Evaluating Users' Household-Size and Housing Quality in Osogbo, Nigeria. Ethiopian Journal of Environmental Studies and Management, 3(2). doi: 10.4314/ejesm.v3i2.59825

66. Jirón, P., \& Fadda, G. (2003). A quality of life assessment to improve urban and housing policies in Chile. Retrieved from http://citeseerx.ist.psu.edu/viewdoc/summary?doi=10.1.1.197.567

67. Kampen, J. K., De Walle, S. V., \& Bouckaert, G. (2006). Assessing the relation between satisfaction with public service delivery and trust in Government. Retrieved from

https://www.researchgate.net/publication/283599865_Assessing_the_relation_between_satisfa ction_with_public_service_delivery_and_trust_in_government_The_impact_of_the_predisposition_ of_citizens_toward_government_on_evaluations_of_its_performance

68. Kasim, R., Ahmad, A. R., \& Eni, S. (2007). Skills for engaging communities in the housing neighbourhood facilities process: the European experience. Retrieved from https://www.researchgate.net/publication/242161901_SKILLS_FOR_ENGAGING_COMMUNITIE S_IN_THE_HOUSING_NEIGHBOURHOOD_FACILITIES_PROCESS_THE_EUROPEAN_EXPERIENCE

69. Khozaei, M., Soleimani, A., Najafi, P., \& Feizi, M. (2007). Effect of Salt Levels and Cropping Methods on Wheat Agronomic Characteristics. Pakistan Journal of Biological Sciences, 10(6), 950-954. doi: 10.3923/pjbs.2007.950.954

70. Kim, J.-N., Hung-Baesecke, C.-J. F., Yang, S.-U., \& Grunig, J. E. (2013). A Strategic Management Approach to Reputation, Relationships, and Publics: The Research Heritage of the Excellence 
Theory. The Handbook of Communication and Corporate Reputation, 197-212. doi: 10.1002/9781118335529.ch18

71. Kothari, C. R. (2011). Research methodology: Methods and techniques (2nd ed.). New Delhi: New Age International.

72. Kowaltowski, D. C. C. K., da Silva, V. G., Pina, S. A. M. G., Labaki, L. C., Ruschel, R. C., \& de Carvalho Moreira, D. (2006). Quality of life and sustainability issues as seen by the population of lowincome housing in the region of Campinas, Brazil. Habitat International, 30(4), 1100-1114. doi: 10.1016/j.habitatint.2006.04.003

73. Krejcie, R. V., \& Morgan, D. W. (1970). Determinining Sample Size for Research Activities . Retrieved from https://home.kku.ac.th/sompong/guest_speaker/KrejcieandMorgan_article.pdf

74. Kurian, M. S., Thampuran, A. (2011). Assessment of Housing Quality. Institute of Town Planners, $8(2), 74-77$.

75. Lan, H. (2011). A study on Housing Preference of Young households Using Stated-Preference Approach. Retrieved from http://kth.divaportal.org/smash/get/diva2:460839/FULLTEXT01.pdf

76. Lauster, N. T. (2008). Better Homes and Families: Housing Markets and Young Couple Stability in Sweden. Journal of Marriage and Family, 70(4), 891-903. doi: 10.1111/j.17413737.2008.00534.x

77. Lawrence, R. J. (2004). Housing and health: from interdisciplinary principles to transdisciplinary research and practice. Futures, 36(4), 487-502. doi: 10.1016/j.futures.2003.10.001

78. Lee, C., Dobson, A., Brown, W., Bryson, L., Byles, J., Warner-Smith, P., \& Young, A. (2005). Cohort Profile: The Australian Longitudinal Study on Women's Health. International Journal of Epidemiology, 34(5), 987-991. doi: 10.1093/ije/dyi098

79. Levy, D., Murphy, L., \& Lee, C. K. C. (2008). Influences and Emotions: Exploring Family Decisionmaking Processes when Buying a House. Housing Studies, 23(2), 271-289. doi: 10.1080/02673030801893164

80. MacCarty, M. (2014). Introduction to public housing. Retrieved from https://fas.org/sgp/crs/misc/R41654.pdf

81. Macpherson, R., Shepherd, G., \& Thyarappa, P. (2012). Supported accommodation for people with severe mental illness: an update. Advances in Psychiatric Treatment, 18(5), 381-391. doi: 10.1192/apt.bp.110.008714

82. Mahon, J. F. (2002). Corporate Reputation. Business \& Society, 41(4), 415-445. doi: 10.1177/0007650302238776

83. Mahon, J. F., \& Wartick, S. L. (2003). Dealing with Stakeholders: How Reputation, Credibility and Framing Influence the Game. Corporate Reputation Review, 6(1), 19-35. doi: 10.1057/palgrave.crr.1540187

84. Marston, G. (2004). Managerialism and public housing reform. Housing Studies, 19(1), 5-20. doi: $10.1080 / 0267303042000152140$

85. Matthews, R. J., Smith, L. K., Hancock, R. M., Jagger, C., \& Spiers, N. A. (2005). Socioeconomic factors associated with the onset of disability in older age: a longitudinal study of people aged 75 years and over. Social Science \& Medicine, 61(7), 1567-1575. doi: 10.1016/j.socscimed.2005.02.007

86. McArthur, T. (2005). The first English learner's dictionary: the Chinese dimension. English Today, 21(1), 60-64. doi: 10.1017/s0266078405001148

87. McTarnaghan, S., Martín, C., Srini, T., Collazos, J., Gold, A., Suminski, M., \& Guzman, Y. (2016). Literature Review of Housing in Latin America and the Caribbean. Retrieved from https://www.urban.org/sites/default/files/publication/84806/2000957-Literature-Review-ofHousing-in-Latin-America-and-the-Caribbean.pdf 
88. Melewar, T. C., Karaosmanoglu, E., \& Paterson, D. (2005). Corporate identity: concept, components and contribution. Journal of General Management, 31(1), 59-81. doi:

10.1177/030630700503100104

89. Mitchell, J., \& Weale, M. R. (2007). The rationality and reliability of expectations reported by British households: micro evidence from the British household panel survey. Retrieved from https://papers.ssrn.com/sol3/papers.cfm?abstract_id=2785294

90. Mohit, M. A., \& Azim, M. (2012). Assessment of Residential Satisfaction with Public Housing in Hulhumale', Maldives. Procedia - Social and Behavioral Sciences, 50, 756-770. doi: 10.1016/j.sbspro.2012.08.078

91. Moreno, R. (2011, January). Policymaking from a 'macroprudential' perspective in emerging market economies. Retrieved from https://www.bis.org/publ/work336.pdf

92. Morris, A. K., \& Hiebert, J. (2009). Introduction: Building Knowledge Bases and Improving Systems of Practice. The Elementary School Journal, 109(5), 429-441. doi: 10.1086/596994

93. Morris, E. W., \& Winter, M. (1978). Housing, Family and Society. New York: Wiley.

94. Mukhija, V. (2004). The Contradictions in Enabling Private Developers of Affordable Housing: A Cautionary Case from Ahmedabad, India. Urban Studies, 41(11), 2231-2244. doi: 10.1080/0042098042000268438

95. Niedomysl, T. (2008). Residential Preferences for Interregional Migration in Sweden: Demographic, Socioeconomic, and Geographical Determinants. Environment and Planning A: Economy and Space, 40(5), 1109-1131. doi: 10.1068/a39177

96. Niemeyer, S. M., Bruin, M., Cook, C. C., Laux, S., Memken, J., White, B. J., ... Yust, B. (2007). Local Housing and Service Decisions. Journal of Housing for the Elderly, 20(4), 5-22. doi:

10.1300/j081v20n04_02

97. Norquist, K. (2009). Local Preferences in Affordable Housing: Special Treatment for Those Who Live or Work in a Municipality. Retrieved from

https://lawdigitalcommons.bc.edu/cgi/viewcontent.cgi?referer=\&httpsredir=1\&article=1005\& context=ealr

98. Nubi, O. T. (2008, October). Affordable Housing Delivery in Nigeria. Cape Town.

99. Okewole, I. A., \& Aribigbola, A. (2006). Innovations and sustainability in Housing Policy Conception and Implementation in Nigeria. In The Built Environment: Innovation Policy and Sustainable Development (pp. 414-420). Ota: Covenant University.

100. Olawande, O. A. (2010, April). Arterial Road Network and Commercial Property Values: Case Study of Ikeja, Nigeria. Retrieved from

http://eprints.covenantuniversity.edu.ng/107/1/Arterial_Road_Network_and_Commercial_Pro perty_Values\%5B1\%5D.pdf

101. Olotuah, A. O. (2010). Housing development and environmental degeneration in Nigeria. The Built \& Human Environment Review, 3, 42-48.

102. Olotuah, A. O., \& Taiwo, A. A, (2015). Housing Strategies and Quality of Housing in Nigeria: What lessons from Wales. Developing Country Studies, 5(16), 1-5.

103. Oso, Y. W., \& Onen, D. (2009). A General guide to writing research proposal and report. Nairobi: Jomo Kenyata Foundation.

104. Pallant, J. (2016). SPSS Survival Manual: A step by step guide to data analysis using SPSS (6th ed.). Maidenhead: Open University Press.

105. Park, I.-S., Kim, J.-H., \& Kim, J.-J. (2008). The Effects of the Residential Satisfaction and Brand Image on the Customer Loyalty in the Apartment Market. Journal of the Architectural Institute of Korea. Planning \& Design, 24(9), 57-64. 
106. Parkes, A., Kearns, A., \& Atkinson, R. (2002). What Makes People Dissatisfied with their Neighbourhoods? Urban Studies, 39(13), 2413-2438. doi: 10.1080/0042098022000027031

107. Riaz, A., Muhammad, S., Ashraf, I., \& Zafar, M. I. (2012). Role of Punjab rural support program in improving economic conditions of rural women through micro financing. Pakistan Journal of Agricultural Sciences, 49(2), 211-216

108. Rojas, E. (2014). Housing Policies, Quality of Housing and Urban Development. Lessons from the Latin American Experience 1960-2010.

109. Roske, M. D. (1983). Housing in Transition. New York: Holt, Rinehart and Winston.

110. Salleh, N. A., Yusof, N., Salleh, A. G., \& Johari, N. (2011). Tenant Satisfaction in Public Housing and its Relationship with Rent Arrears: Majlis Bandaraya Ipoh, Perak, Malaysia. International Journal of Trade, Economics and Finance, 10-18. doi: 10.7763/ijtef.2011.v2.72

111. Schultz, F., Castelló, I., \& Morsing, M. (2013). The construction of corporate social responsibility in network societies: A communication view. Journal of business ethics, 115(4), 681-692.

112. Shi, L. (2005). Housing preferences of residents in Stellenbosch, South Africa. Retrieved from https://core.ac.uk/download/pdf/37322137.pdf 